KRONOS | AGOSTO 2021-ENERO $2022 \mid$ vol. $02 \mid$ n. $^{\circ} 1$

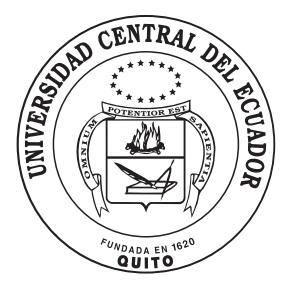

ISSN-I 2631-2840 | ISSN-E 2631-2859

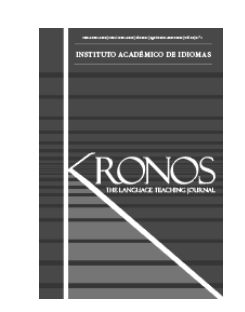

\title{
A METHODOLOGICAL STRATEGY IN FOREIGN LANGUAGE TEACHING THROUGH ARTISTIC CREATIONS WITH SEEDS
}

\section{UNA ESTRATEGIA METODOLÓGICA EN LA ENSEÑANZA DE LENGUAS EXTRANJERAS A TRAVÉS DE CREACIONES ARTÍSTICAS CON SEMILLAS}

Eugenia Proaño

Universidad Técnica del Norte

https://orcid.org/0000-0002-5510-5139

\author{
Ernesto Muñoz \\ Universidad Técnica del Norte \\ https://orcid.org/0000-0002-9502-5889
}

\author{
María Rosa Ferigra \\ Universidad Central del Ecuador \\ https://orcid.org/0000-0002-7334-2947
}

Recibido: 13 de mayo 2019

Aprobado: 30 de abril 2021

DoI: 10.29166/kronos.v2i1.1698
KEYWORDS Methodological strategy, seeds, images, rods, writing skill.

PAlabras Clave Estrategia metodológica, semillas, imágenes, paletas, habilidad de escritura.

\begin{abstract}
Language teaching strategies in the English language classroom as a foreign language have changed significantly in the last few decades. New approaches and different materials have risen in the learning process. This action research focused on the use of seeds as didactic material and idea generator in the development of the writing process with university students from Técnica del Norte University - Ibarra and Central University- Quito. The data were obtained through the application of a survey and observation. A description of what was observed was recorded in each stage of the process while using seeds as a methodological strategy. Results showed that when designing and seeing figures, a 'rock-slide' of thoughts emerged from students for writing. Students simply expanded their horizons with their creativity because this new strategy gave them liberty to express themselves openly. They were more than able to reaffirm their intellectual capacities when learning the foreign language.
\end{abstract}

\section{RESUMEN}

Las estrategias de enseñanza de lenguaje en el aula de inglés como lengua extranjera han cambiado significativamente en las últimas décadas. Nuevas técnicas y diferentes materiales han surgido en el proceso de enseñanza. Esta investigación acción está enfocada en el uso de semillas como material didáctico y generador de ideas en el desarrollo del proceso de escritura con estudiantes universitarios de la Universidad Técnica del Norte-Ibarra y de la Universidad Central del Ecuador-Quito. Los datos fueron obtenidos a través de la aplicación de una encuesta y la observación. Una descripción de lo que fue observado se registró en cada etapa del proceso al utilizar semillas como estrategia metodológica. Los resultados mostraron que cuando se diseña y se observa imágenes, una lluvia de ideas emerge en los estudiantes para la escritura. Los estudiantes simplemente expandieron sus horizontes con su creatividad porque esta nueva estrategia les dio libertad para expresarse ampliamente. Ellos pudieron reafirmar sus capacidades intelectuales al aprender el lenguaje extranjero. 


\section{INTRODUCTION}

Language teaching strategies in the English language classroom as a foreign language have changed significantly in the last few decades. New approaches and different materials have risen in the learning process. The use of seeds can be an alternative material to be used in the classroom. Seeds are not only inventive but provide a tactile resource usually wasted and thrown away; equally, it is cheap and easy material to obtain. With this strategy, students are provided the opportunity to be creative, express their opinions, and develop critical thinking. Although everyone has something to say, not everyone is given the opportunity to do so. Working with seeds contributes to this purpose in a relaxing environment, in which students are reassured and can set free their imagination (Robinson, 2009).

Finding motivation to achieve a task can become a nuisance for students, as some of them come from different backgrounds where learning a new language had no importance. Brown (2000) mentions on his book Learning by principles that when given the opportunity to do language for their personal interests; students succeed at becoming independent and motivated. Through working with new materials and resources, students have a chance to create pieces of art drawing inspiration from their own creative minds, becoming little by little aware of their own abilities and getting motivated for a better learning.

Shifting the focus of the classroom has become inevitable in the language classroom. The role of the student must be an active one as they are the ones learning the subject. The use of seeds to create mosaics gives them a chance to be themselves, act on their imagination, and become independent in their own learning. Linse \& Nunan $(2005$, p.7) mentions in his work that the effects of traditional methods have been greatly unsatisfactory. A change in methodology can always open doors to improving the teaching and learning of a foreign language.

Generally, the English as a foreign language (EFL) classroom material refers to the course books widely offered by editorials. However, this paper is based on the use of seeds as didactic material. Seeds are principally used in sowing, but appropriately dried, they can serve as a tactile resource to be easily manipulated in the classroom. They can be used as Harmer suggests as any other «object for involving students in activities of all kinds» (2007, p. 177), whether to learn Math or to create art; their use will awaken students' senses meaningfully.

Language teachers provide students a wide range of materials which help to augment the acquisition of the English language. The didactic material employed spans the more traditional approach to the not-so-tra- ditional methods-of knowledge-acquisition. Simple paper is used, posters, balls, varieties of plastic objects to take advantage of, toys, and clothes to mention some. The vision spreads out very far and beyond the aforementioned examples provided that seeds are a precious natural resource.

The question arises here. How are seeds used in a language class? Are they just seeds? What is there to talk about seeds? They can be reused as the raw material needed to create artistic picture designs. From these images, learners organically generate ideas necessary in the composition of English. Similarly, as stated by Janovsky (2015), when students have the opportunity to use a graphic organizer, they can create their own illustrations and this can be a great way to incorporate active learning experiences in the classroom. Starting there, the demonstration of the student's consummate creativity was astounding. Students' designs and compositions were totally original. Everything was spawned from their minds and hearts.

\section{Literature review}

This article reports on an action research and innovation project focused on the use of seeds as didactic material in the writing skill. This research was inspired on the work of other teachers as for example, Mary Scholl, Costa Rica, (2016) who uses rods, colored stones, cards, dice, even real food to create stories with them and promote the language learning. Also, a teacher from Dirección de Educación (2001) who mentioned that in the countryside teachers use seeds as educational material due to its availability and a teacher of natural sciences Colegio Bilingüe (2009) who created with her students a seed bank to preserve them. In other words, didactic material can be any element that might contribute to the teaching-learning process in the classroom in which learners become active constructors of their own learning and teachers, facilitators of it (Moreno, 2013).

Even though there is no research about the benefits of seeds as didactic material in the language classroom, the present research aims at exploring how seeds contribute to language learning. This project takes as reference the studies carried out by Arnold, Puchta \& Rinvolucri (2007) about imagery in the EFL classroom. Harmer and Scrivener (2011) about the use of Cuisenaire rods as tactile tools for learning.

\section{Mental images}

Arnold et al. (2007) present solid reasons for dealing with imagery in language teaching. For them, imagery work can contribute significantly to our students' language learning in direct or indirect work; among others they can increase learners' cognitive skills and 
their creativity, provide things they want to say when they write, enhance their motivation, and help to focus their attention. These mental images first conceived in students' minds are then represented in a picture design worked with seeds which can be visualized by everybody but mainly by the authors who will use it as idea generator to write their compositions.

The neurologist Antonio Damasio explains that images are what 'mind' is actually made of. He goes on to state that an essential condition for mind is the ability to display images in a process called thought, Damasio (1994), (cited in Arnold et al., 2007, p. 89-90). Therefore, the mental images that little by little take form on a canvas with the use of seeds also generate ideas in a piece of writing because both the picture design and the composition are closely related. Boosting intrinsic motivation through tactile material (seeds) in the language classroom will help students spark their artistry that all have inside secretly hidden.

Dornyei in his discussion of motivation and self-motivation presents the concept of the ideal language self. He explains that if in your ideal vision of yourself there is a facet associated with knowing the L2; this can act as a strong motivational force (cited in Arnold et al., 2007). Teachers need to ensure their students that knowing English can be attractive and possible for them when they picture themselves as fluent users of the language either speaking or writing and the illustrations they create help them reach this goal because these images can take them wherever they want to go.

\section{Cuisenaire rods}

What are Cuisenaire rods? «Cuisenaire rods are small colored blocks of wood or plastic that come in different lengths. Originally used in primary Math teaching, they have become a very useful language-teaching aid. They first became widely known as a feature of Caleb Gattegno's Silent Way approach in the 1970s» (Scrivener, 2011, p. 300). Seeds are somehow similar to rods. Seeds come in different colors, textures, shapes, volume and sizes and originally they were used in Mathematics. Seeds can be used as another visual and manipulative aid, which is tangible, and the students can pick them up, move them around, play and create a scene with them in the way their images come to their minds.

According to Harmer (2007), rods help students to focus in on meanings, ideas, stories, language items, etc. In a similar way, seeds can provide language learners with an opportunity to develop imagination and creativity in an experience that requires concentration and a narrowing of attention. This was reflected in the testimony of a student who said «I, personally, became so focused on what I was doing when working with seeds that I sometimes drifted out of thought. I was totally immersed in the present. I seemed to be drifting out of time and space, where every moment seemed to be as long as the life-age of Mother Earth». "Creativity is also necessary for survival. The history of our species can be mapped with reference to key creative breakthroughs: agriculture, the wheel, writing systems, printing - a cumulative and constantly proliferating series of discoveries and inventions» (Peachey \& Maley, 2015, p. 9).

\section{Incorporating picture designs}

Same as when using graphic organizers, the implementation of picture designs with seeds served as vocabulary lists that students alone made. Some learners are just more naturally visual. They are inclined to learn with their eyes. They comprehend figures faster. From seeing figures, a 'rock-slide' of thoughts emerged from students when writing. Students simply expanded their horizons with the designs of seeds. Their creativity could grow spontaneously. Moreover, their tasks gave them liberty to express themselves openly in a written way. They were more than able to reaffirm their intellectual capacities. They further developed their abilities in using the English Language.

\section{Writing in a foreign language}

Writing is communicating thoughts and ideas through the written word. Writing competence comes from how you write and consummately grows depending on what is written (Zemach \& Stafford, 2010). In order to be able to excel at these tasks, as well as to accomplish them, students need to have exercised certain abilities previously related to the structure of how to compose simple, compound and complex sentences to eventually write a paragraph. Can they express an argumentative idea? Is there cohesion in what is said? Does it make sense or is the writing coherent? How is the grammar? Is the lexical-resource employed able to articulate proposed ideas? Is the punctuation correctly utilized?

As the aforementioned authors affirmed, writing artistic entrepreneurships is a process. The writer naturally passes through different stages until achieving a final product. Once students understand how the writing process works in short compositions and essays, they will gain the necessary confidence to dive into the higher academic levels of communication.

Prior research has identified areas of difficulty when acquiring a second language regarding writing. This occurs due to the first language interference (Hinkel, 2015). The author has identified some elements of weak writing as for example, the over-use of the verb 'to be' as well as other verbs, starting a sentence without a subject, using the noun before an adjective, dropping s-es in the 'third-person' in simple present', not 
using the auxiliary to ask a question. Such examples as these are enhanced with practice. They are some of the challenges and habits of first (L1) and second language writers.

These common-errors are observed in class activities sent as homework as well as in written texts that are produced by the students, in order to be evaluated by tests. The tests prove the proficiency and efficiency of the students. When being successful, students can receive certification as a requirement before graduating from university. The aforementioned common-errors are on account of the mother-tongue; which is still quite strong. This project aims at helping the acquisition process of writing and joyfully removes filters that may hinder the acquisition of stellar and communicative English.

\section{Methodology}

\section{PARTICIPANTS AND SETTING}

The participants were university students belonging to different faculties: Centro Académico de Idiomas (CAI), English Major and Graphic Design from Técnica del Norte University-Ibarra and Carrera Plurilingüe from Central University-Quito. The students were between the ages of 19-25. They were both male and female. The study was carried out in two-hour sessions with each group of students.

\section{MATERIALS}

The store house of seeds available has been collected by the teachers for more than three years. The material comes from several types of fruit, like mamey, plums, tamarind, guanabana, cherry, cherimoya, sapote, and peach, shells of pistachio, walnut, and the seeds of other plants, like huairuro, caimito, acacia, tortas, visola, and san pedro. They belong to the three different regions of Ecuador, the Coast, Highlands and the Amazon Region. Galápagos is excluded, because «Consejo de Gobierno del Régimen Especial de Galápagos» has a law that prohibits anybody from introducing or removing anything that can damage the ecosystem in this protected area, Control ambiental art. 82 al 85 (2015). So, there is nothing from the Galapagos province. The fruit seeds have been obtained following certain detailed steps.

\section{PROCEDURE}

The fruit is first eaten. The seed is removed. It is then rubbed with a sponge and washed with water. Next, all the remaining parts of the fruit-pulp are diligently removed with a tooth-pick until all is completely clean, or picked-out. At long last, the seeds are exposed to the sun to let them dry a bit. The drying process can take several days. If a seed is not dried well enough, it runs the risk of becoming spoiled. When ready, the best seeds are lovingly selected. Despite being well cleaned, it is interesting to note that the seeds maintain their former characteristics of color, size and texture. Seeds of different plants that are harvested directly from trees are dried before being used. All seeds are stored in jars with the caps seals shut to avoid a possible invasion of hungry moths that would incessantly feast on these precious little seeds.

\section{DATA COLLECTION}

The information was gathered through the application of a survey to the students who participated in the study. The survey was validated by well-experienced teachers, working at CAI and the English major at FECYT of UTN, and a professor from Central University. A description of what was observed was recorded in each stage of the process while using seeds as a methodological strategy.

\section{DATA ANALYSIS}

The information was processed after completing the task of designing and writing. Significant results were identified from the students' answers and teachers' observations which helped to draw the following findings.

The materials, namely the seeds, were a medium that most of the students hadn't worked with since they were in primary school. This fascinated them, as was evident by their enthusiasm and engagement with the activity. The different colors, forms, sizes and textures gave them an outlet to express themselves creatively, which provided them an opportunity to use their language learning in a way that has not been visited upon in a very long time. They were also given the opportunity to adjust their own presence in the learning environment, like sitting or lying on the floor, or in other ways that did not inhibit their creative expression while doing their projects. By working in pairs, they developed new experiences in teamwork, communicating in the target language without the inhibition usually associated with formal language learning. This manifested in a mutual respect for one another through the sharing of ideas and concepts, that may not usually be achieved by traditional language learning means.

This way of working facilitated creativity in the creation of original work, giving the students a sense of ownership over the projects they were developing. They felt free to express their own ideas while at the same time they valued and respected their teammates ideas and creations. This supported an environment of tolerance for others, their culture and ethnicities as Kaplan (2019) claims in her article 6 Essential Strategies 
for Teaching English Language Learners that creating a supportive environment is about cultivating an appreciation of diversity. The use of materials that might usually be overlooked fostered a new perspective in English as a subject especially when put into the context of an original and untraditional learning environment. They created an art gallery with all of the other teams, where the viewer could walk through and appreciate what the students had made, giving them a feeling of satisfaction that encouraged their abilities and belief of success in the target language.

Overall, the evidence demonstrates that the effect of using alternative materials, in this case seeds, serve as a means to efficiently facilitate conversation as idea generators. It also supported the writing process, as the students had to work together to describe their final projects through written word in a context that represented their experiences, beliefs, culture, interests and needs. It also developed social skills in the target language through concepts including, cooperation, sharing, community building, teamwork and creativity. Besides, Caicedo (2016) manifests that cooperation can be conceived as more than just sharing with others, but also implies having in mind a particular goal and working with enough spirit and responsibility to achieve this goal. Indeed, the students found the project fun and engaging, which greatly supported the learning experience.

\section{DISCUSSION}

The seeds worked well as an economic medium which were found to be a convenient yet inspirational tool in the EFL classroom. Though there is no research specifically applied to seeds, the use of everyday items has been documented to demonstrate benefit in the classroom. Such items help to initiate thought, allowing the students to access their imagination which facilitates conversation and descriptive writing. Developing artwork greatly contributes to this creative process, which work hand in hand to generate an overall fully engaging learning environment.

The use of seeds mimics the use of tactile material applied in almost all other content areas. Examples of this include colored rods in Mathematics, models in Science, or creating posters in History. The seeds gave the students a solid, non-abstract item that helped them to focus their creative energy and move into the target content without many of the inhibitions that may be associated with traditional learning strategies. The students would become lost in thought by creating something new and innovative.

The methodology described in this activity represents a holistic learning strategy that appeals not only to visual learners, but all of the different types of learners because it lends itself to such multifaceted strategies. Working as teams also helped students, who normally might be reserved in expressing themselves verbally or through writing in English, find confidence and support which supported them working outside of their normal comfort zones. The idea behind this strategy, as is shown evident through the final products created by the students, was not to accomplish the forms of communication flawlessly but to get to the essence of communication and language by getting across ideas and thoughts without the inhibitions of formal, traditional means. This methodological strategy in the foreign language teaching has turned out to be a positive alternative to avoid students' frustration, demotivation and drop out when facing writing challenges as it is mentioned in the studies carried out by (Lou \& Noels, 2017) cited in (Douglas, 2019).

An example of a written text produced by Jorge Morales and Erick Taimal (UTN English major students, first semester, 2017).

The Andean condor

The condor freely soars about the Andes Mountains in splendor beneath the shining sun!

The Andean Condor gazes down, from on high, and sees that there are waterfalls cascading downwards. It inhales the pure Andean air before descending to join its mate on the edge of a special crag.

A condor's plumage is black. It is a very large bird. It has feathers lining the edge of its great wings as well as its bare neck.

Yes. That is correct. You read correctly. The Andean Condor has no feathers around its neck.

Moreover, their head is red and can alter its hue depending on the emotional state of the bird, so don't get them upset!

Condors want to gaze down and see people cultivating 'Little Seeds'.

A condor is also a symbol of spirituality and purity for many conscious people in Ecuador. They are spiritual beings and simply adore the condor, simply for being.

\section{CONCLUSIONS}

Using seeds as a methodological strategy in foreign language classroom allowed the students to engage their intellect with positive and enthusiastic emotion. Their joyful collaboration gave them ways and avenues to give voice to their thoughts and ideas and make them visible in a written way. Their imagination was their only limitation. The students created art that contextualized personal experience and perception. 
They expressed real-life situations that everybody encounters at some point in life.

The use of seeds in the classroom was a fountain of inspiration. Creativity could only bloom. There was great motivation to create a piece of art with their own hands and then build meaning through a first draft of a piece of writing. The students used seeds to communicate not only in the target language, but to reacquaint the youth with art and seeds.

The students and teachers had the opportunity to break the mold that must have been originally set in a traditional writing lesson. Having the freedom and flexibility of choice, students could participate with one another in a holistic, motivating and inspirational environment, guided by the teacher who created a serene space where all could become constructors of knowledge.

The three groups of students involved in this particular project, not only improved at demonstrating personal background-knowledge and learning, but they also made use of 'soft-skills'; such as interacting with the public and working with the community. This innovative tactile strategy/approach is not for every English writing lesson. However, it gives language-teachers a new dimension to be explored when teaching writing in their own classrooms.

\section{REFERENCES}

Arnold, J., Puchta, H., \& Rinvolucri, M. (2007). Imagine that! with $C D-R O M / a u d i o C D$ : Mental imagery in the EFL classroom. Cambridge University Press.

Brown, H. D. (2000). Principles of language learning and teaching (vol. 4). Longman.

Caicedo, P. A. (2016). Using cooperative learning to foster the development of adolescents' english writing skills. Profile Issues in TeachersProfessional Development, 18(1), 21-38.

Douglas, M. (2019). MultiBrief: How to encourage your ELLS. https://exclusive.multibriefs.com/content/howto-encourage-your-ells/education.
Harmer, J. (2007). The practice of English language teaching. Harlow. English: Pearson Longman.

Hinkel, E. (2015). Effective curriculum for teaching L2 writing: Principles and techniques. Routledge.

Janovsky, A. (2015). Instructional materials: Definition, examples \& evaluation-video \& lesson transcript. Study. com. https://study.com/academy/lesson/instructional-materials-definition-examples-evaluation.html.

Kaplan, E. (2019). 6 essential strategies for teaching ELLs. Edutopia. https://www.edutopia.org/article/6-essential-strategies-teaching-english-language-learners.

Linse, C. \& Nunan, D. (2005). Practical English language teaching: Young learners/by Caroline T. Linse; David Nunan, series editor. McGraw-Hill/Contemporary.

LOREg (Ley Orgánica de Régimen Especial de la Provincia de Galápagos). (2016). Ley 0, Registro Oficial Suplemento 520 de 11 de junio de 2015.

Moreno, F. (2013). La manipulación de los materiales como recurso didáctico en educación infantil. Estudios sobre el mensaje periodístico, 19 (Special Issue), 329.

Peachey, N. \& Maley, A. (2015). Creativity in the English language classroom. British Council.

Robinson, K. (2009). The element: How finding your passion changes everything. Penguin.

Scholl, M. (2016). SIT TESOL Course, Costa Rica.

Scrivener, J. (2011). Learning teaching: the essential guide to English language teaching, $3^{\text {rd }}$ ed. Macmillan Education.

Zemach, D. \& Stafford, L. (2010). Writers at work: The Essay Student's Book: The Essay, vol. 1. Cambridge University Press. 